\title{
HISTOLOGICAL STUDY ON THE EFFECT OF Arabidopsis thaliana EXTRACT ON ALLOXAN-INDUCED DIABETIC INFERTILITY MICE
}

\author{
TAHA M.A. ${ }^{1}$, AHMED S.J. ${ }^{1}$ AND RASHID K.I. ${ }^{2}$ \\ ${ }^{1}$ Anatomy Department, College of Medicine, Baghdad University, Baghdad, Iraq. \\ ${ }^{2}$ College of Health and Medical Technologies, Baghdad University, Jadriyah, Baghdad, Iraq. \\ ${ }^{*}$ Corresponding Author: Email- shaymajamal@yahoo.com
}

Received: October 30, 2013; Accepted: April 15, 2014

\begin{abstract}
Arabidopsis thaliana, a small, annual flowering, dicotyledonous plant, is native to Europe, Asia, and northwestern Africa. Now Days, the herbal medicines have gate importance as a source of hypoglycemic agents. Marles and Farnsworth estimated that more than 1000 plant species are being used as folk medicine for diabetes. Insulin-like growth factor 1 (IGF-1), known as "somatomedin C", found in Arabidopsis thaliana seeds.

Type Il diabetes mellitus (also sometime called adult-onset or non insulin-dependent diabetes) is increasing worldwide and it is the most common form of diabetes. It is a syndrome characterized by a loss of glucose homeostasis from defects in insulin secretion and it's action, both resulting in impaired metabolism of glucose and other energy yielding fuel such as lipids and proteins. Male sexual dysfunctions are frequently associated with hyperglycemia in experimental rats and in men. It is well known that in diabetic conditions.

Anti-diabetic medical plants are general known to exert their beneficial effects on diabetes via various modes and mechanism depending on the phytochemicals and bioactive agents endowed in such plants.

In this study the Arabidopsis thaliana ethanolic seed extract has hyperglycemic. In conclusion, the present results showed that Arabidopsis consumption reversed most of the histological changes in the diabetic mice. This effect was due to the hypoglycemic effect of the Arabidopsis and improving the insulin resistance. In addition, in diabetes there was an increase in the oxidative stress which was significantly reduced by Arabidopsis consumption owing to its antioxidant effect.
\end{abstract}

Keywords- Diabetes mellitus, Arabidopsis, Histological Examination

Citation: Taha M.A., Ahmed S.J. and Rashid K.I. (2014) Histological Study on the Effect of Arabidopsis thaliana Extract on Alloxan-Induced Diabetic Infertility Mice. International Journal of Drug Discovery, ISSN: 0975-4423 \& E-ISSN: 0975-914X, Volume 6, Issue 1, pp.-207-212.

Copyright: Copyright@2014 Taha M.A., et al. This is an open-access article distributed under the terms of the Creative Commons Attribution License, which permits unrestricted use, distribution and reproduction in any medium, provided the original author and source are credited.

\section{Introduction}

Arabidopsis thaliana, a small, annual flowering, dicotyledonous plant, was discovered by Johannes Thal (hence, thaliana) in the Harz mountains in the sixteenth century. Arabidopsis is a member of the Brassicaceae family, which includes important crops. It has no agronomic significance, but offers important advantages for basic research in genetics and molecular biology [1].

Insulin-like growth factor 1 (IGF-1), known as "somatomedin C", found in Arabidopsis thaliana seeds, is a single polypeptide protein hormone consisting of 70 amino acids and having a molecular weight of 7,649 Da.It has three intermolecular disulfide bridges and the molecular structure is similar to insulin. IGF-1 plays a major role in cell growth and differentiation; it is involved in various physiological processes in mammals with the regulation of somatic growth and cellular proliferation both in vivo and in vitro. Because of its structural similarity to insulin, IGF-1 has a high potential as a therapeutic agent for a variety of indications, including growth failure, type 1 or type 2 diabetes, amyotrophic lateral sclerosis, severe burn injury, and myotonic muscular dystrophy [2].
Male sexual dysfunctions are frequently associated with hyperglycemia in experimental rats and in men [3,4]. It is well known that in diabetic conditions, the reproductive changes include reduction of male organ and body weights $[5,6]$ oligospermia $[7,8]$, diminished fertility [9], decreased testosterone and gonadotropin levels $[5,8]$ depletion of spermatogenesis and testicular damage $[10,11]$. Another usual consequence of hyperglycemia is the increased oxidative stress which is extremely toxic to cells and exerts its devastating effects by directly damaging cellular proteins, lipids, and DNA, or indirectly, by affecting normal cellular signaling and gene regulation $[12,13]$.

\section{Materials and Methods \\ Plant Material and Extraction Method}

Seeds of Arabidopsis thaliana were obtained local market. The powdered material of seeds (50 gram) added to $250 \mathrm{ml}$ of distilled water, left over night on stirrer, the extract then dried under reduced pressure and was subjected to various chemical tests to detect the presence of different active phytoconstituents like alkaloids, tannins, flavonoids, saponins, terpens and steroids [14]. 


\section{Detection of Some Active Compounds}

This detection was carried out using chemical reagents to determine the presence of the active compounds only without quantification or determination of their types. Flavonoids were extracted by well established method of Harborne 1984, and the procedure has also been followed by several others authors. The extraction protocol which has been carried out in this investigation is only for detection of flavonoids in seed extract of $A$. thaliana.

\section{Detection of Tannins}

(10 gram) of plant powder was mixed with $50 \mathrm{ml}$ distilled water in a magnetic stirrer. The mixture was boiled in a boiling water bath for few minutes, then filtered and the filtrate was treated with few drops of $1 \%$ lead acetate solution. The development of greenish-blue precipitate is an indicator for the presence of tannins [15].

\section{Detection of Saponins}

Saponins were detected by two methods: The first method, aqueous extract of $A$. thaliana seeds powder was shaken vigorously with distilled water in a test tube. The formation of foam standing for a time indicates a positive result. The second method, five milliliters of aqueous extract of the plant was added to 1-3 drops of $3 \%$ ferric chloride solution, a white precipitate was developed which indicates a positive result [16].

\section{Detection of Terpenes and Steroids}

$(1 \mathrm{ml})$ of ethanolic extract was participated in a few drops of chloroform, then a drop of acetate anhydride and drop of concentrated sulfuric acid were added, brown precipitate appeared which representing the presence of terpene, and the appearance of dark blue color after few minutes would represent the present of steroids [17].

\section{Detection of Flavonoids}

Ethanolic extract was partitioned with petroleum ether $(1: 1 \mathrm{v} / \mathrm{v})$, the aqueous layer was mixed with the aluminum solution. The appearance of dark color is an evidence for the presence of flavonoids. Flavonoids react with the reagent and give colour reactions. Spraying reagents $5 \%$ fehling solution and $1 \% \mathrm{AICl} 3$ solution are exclusively used to detect flavonoids [17].

\section{Detection of Alkaloids}

(10 gram) of the extract was boiled with $50 \mathrm{ml}$ of distilled water and $4 \%$ of hydrochloric acid was added, then the solution was filtered and cooled. $0.5 \mathrm{ml}$ of the supernatant was tested with Mayer solution, appearance of white precipitate indicates the presence of alkaloids [17].

\section{Experimental Animals and Diabetes Induction}

Healthy 15 adult male albino mice of Swiss albino strain were obtained from the animal house of the College of Medicine, Baghdad University. The mice age was 8 weeks, and its weight was $25 \mathrm{gram}$. The animals were housed in clean cages, sterilized weekly with $70 \%$ ethanol. The mice were kept in with natural 14 hours light, 10 hours dark, at a controlled temperature $\left(24-28^{\circ} \mathrm{C}\right)$. The animals were fasted for 24 hours, then diabetes was induced by a single intraperitoneal injection of alloxan monohydrated dissolved in distilled water at a dose of $150 \mathrm{mg} / \mathrm{kg}$ of mice body weight in volume of $0.1 \mathrm{ml}$. The diabetic state was confirmed 72 hours after alloxan injection. Blood glucose value was reached $320 \mathrm{mg} / \mathrm{dl}$ which indicate hyperglycemia (120-140 mg/dl) as standard before treatment, and there was $4 \%$ mortality in animals treated with alloxan.

\section{Histological Investigation}

The testis was fixed in 10\% formalin and processed for light microscopic study to get paraffin sections of $5 \mu \mathrm{m}$ thickness. Sections were stained with Haematoxylin and Eosin (Hand E) and PAS technique [18].

\section{Results}

\section{Chemical Tests for Detection of Some Active Compounds}

[Table-1] show the chemical test of the active compounds in Arabidopsis thaliana seed extract.

Table 1- The chemical test of the active compounds in Arabidopsis thaliana seed extract.

\begin{tabular}{|llc|}
\hline No. & Compound & Result \\
\hline 1 & Tannins & + \\
2 & Flavonoids & + \\
3 & Alkaloids & + \\
4 & Saponins & + \\
5 & Terpenes and Steroids & + \\
6 & Glycoside & - \\
\hline
\end{tabular}

${ }^{*}(+)$ means positive detection, (-) means negative.

\section{Hypoglycemic Effect}

[Table-2] showed that the daily treatment with Arabidopsis thaliana ethanolic extract of $200 \mathrm{mg} / \mathrm{kg}$ b.w. led to a significant reduction in the blood glucose levels after $3,6,9$ days of the treatment which recorded 192, 154, $132 \mathrm{mg} / \mathrm{dl}$ respectively.

The effect seems to reach maximum on $12^{\text {th }}$ day of the treatment period $(121 \mathrm{mg} / \mathrm{dl})$ with ethanolic extract and then became stable as control treatment. Significant reduction in blood glucose level was observed as compared to the normal group $(119 \mathrm{mg} / \mathrm{dl})$ and diabetic group $(320 \mathrm{mg} / \mathrm{dl})$ after 12 days with gradually reduction till reached $121 \mathrm{mg} / \mathrm{dl}$ at the end of the experimental period (12 days).

\section{Histological Effect}

Examination of $\mathrm{H}$ and $\mathrm{E}$ stained sections of control testes showed seminiferous tubules and interstitial tissue in-between containing clusters of Leydig cells with their vesicular nuclei and vacuolated acidophilic cytoplasm. Tubules were surrounded by well-defined basement membrane which was lined by a stratified epithelium consisted of Sertoli cells and spermatogenic cells. Both Sertoli cells and spermatogonia were seen resting on the basement membrane which was surrounded by myoid cells with flat nuclei [Fig-1](A). Examination of PAS stained sections of the same group showed regular PAS positive basement membrane as well as acrosomes of the head cap of spermatids [Fig-2](A).

Table 2- Effect of $A$. thaliana seed ethanolic extract on reducing blood glucose levels of white albino mice after different periods of time

\begin{tabular}{|c|c|c|c|c|c|c|c|}
\hline Group/treat & Dose & 0 days & 3 days & 6 days & 9 days & 12 days & p-value \\
\hline Normal mice & $0.1 \mathrm{ml}$ distilled $\mathrm{H}_{2} \mathrm{O}$ & 122 & 121 & 119 & 123 & 119 & \\
\hline Induce diabetic mice (Alloxan) & $0.1 \mathrm{ml}(150 \mathrm{mg} / \mathrm{kg})$ & 314 & 316 & 312 & 309 & 320 & 0.046 \\
\hline Diabetic mice (Arabidopsis ethanolic extract) & $0.1 \mathrm{ml}(200 \mathrm{mg} / \mathrm{kg})$ & 278 & 192 & 154 & 132 & 121 & \\
\hline
\end{tabular}




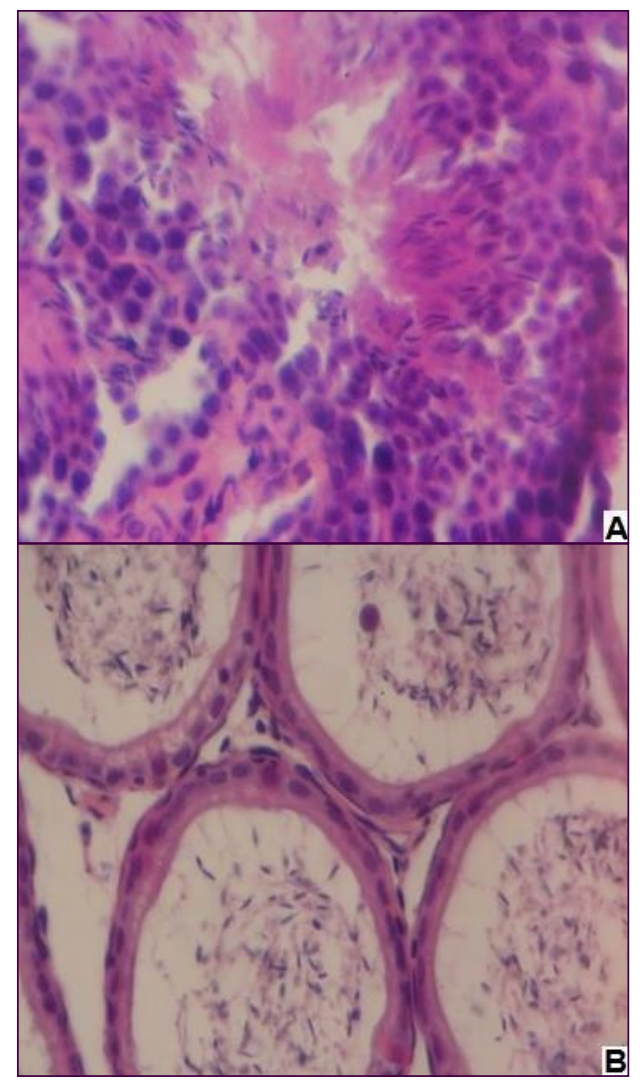

Fig. 1- Testis of control animals showing (A) the seminiferous tubules lined by several layers of spermatogenic epithelium with clusters of interstitial Leydig in-between the tubules and (B) epididymis containing sperm reserve (H\&E) X400.

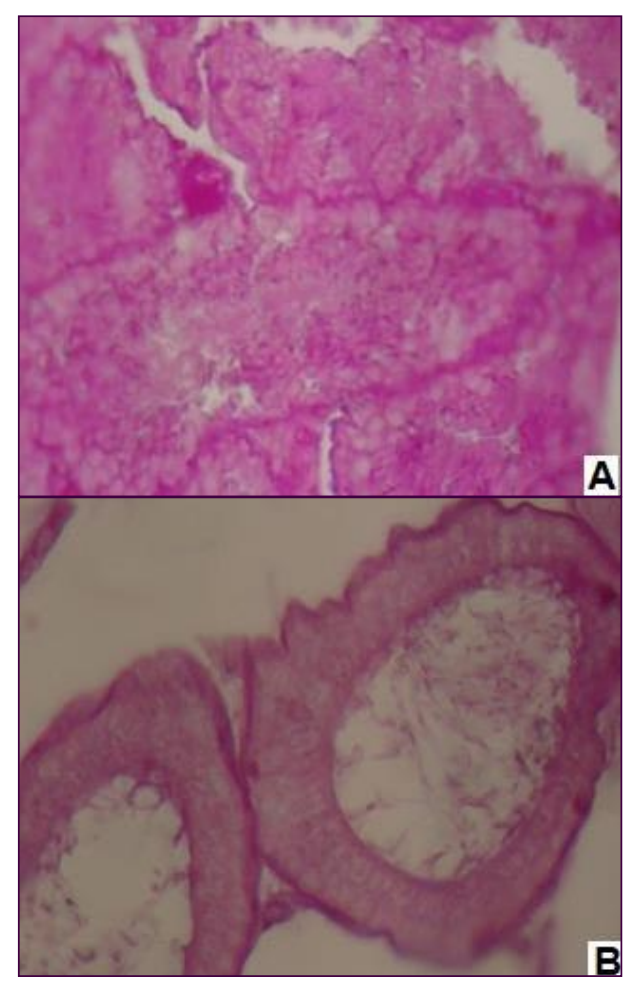

Fig. 2- Testis of control animal showing (A) PAS positive reaction of basement membrane and acrosomal caps of early spermatids and spermatozoa in the lumen of the tubule and (B) epididymis with PAS positive basement membrane. PAS X400.
Examination of $\mathrm{H}$ and $\mathrm{E}$ stained sections of diabetic animals without treatment showed irregular seminiferous tubules [Fig-3](A). Most of these tubules were depleted from their spermatogenic cells. They were lined by Sertoli cells, few spermatogonia and few primary spermatocytes with dark condensed nuclei. Giant multinucleated cells were seen inside the tubules. Some degenerated spermotozoa could be detected in the lumen of the tubules [Fig-3](B) and [Fig-4] (A). The widened interstitial tissue appeared vacuolated with exudation [Fig-4](B). PAS stained sections of the same group showed apparently thickened PAS positive basement membrane of the seminiferous tubules as well as exudative materials in the interstitial tissue.

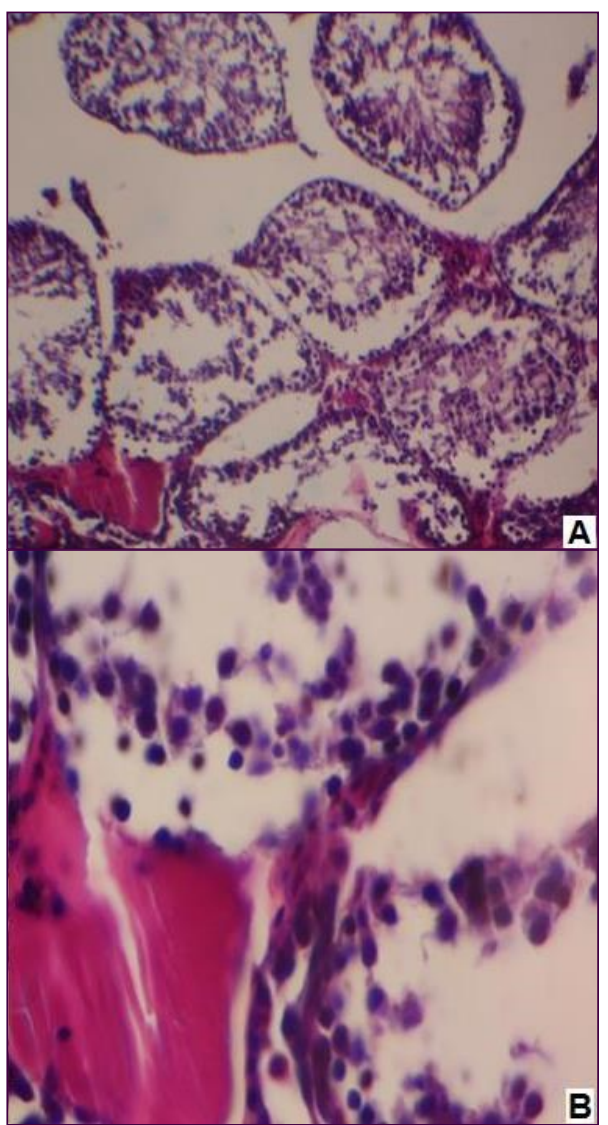

Fig. 3- Testis of diabetic animals showing $(\mathrm{A})$ irregular seminiferous tubules and (B) spermatogenic cells are fewer in number with widening of the spaces between cells compared to the control group. Notice exudation of the interstitial tissue with mononuclear cells infiltration (H\&E) A X100, BX 400.

PAS positive reaction of acrosomal caps was nearly absent in the cells lining the wall of the tubules [Fig-5](A\&B) and [Fig-6](A). Examination of $\mathrm{H}$ and $\mathrm{E}$ stained sections of diabetic animals receiving Arabidopsis showed that the seminiferous tubules were lined by several layers of spermatogenic cells. Spermatogonia and Sertoli cells were seen resting on the basement membrane followed by primary spermatocytes, early and late spermatids nearly similar to the control group [Fig-7](A). PAS stained sections of the same group showed nearly regular and apparently thinner PAS positive basement membrane compared to diabetic group receiving no treatment. Acrosomal caps of early spermatids and late spermatids showed PAS positive reaction nearly similar to the control group [Fig-8](A). The epididymis in control group contained sperm reserve while in hyperglycemic groups, the epididymal duct epithelium was 
higher than in normoglycemic animals and they contained no sperm reserve [Fig-1](B) and [Fig-4](B). $\mathrm{H}$ and $\mathrm{E}$ stained sections of Arabidopsis-treated diabetic animal were nearly similar to those of control group and they contained sperm reserve [Fig-7](B). PAS stained sections of epididymis of diabetic animals exhibited PAS positive reactions of both basement membrane and luminal border which were apparently thickened than those of control and Arabidopsis-treated diabetic groups [Fig-2](B), [Fig-6](B), [Fig-8](B).

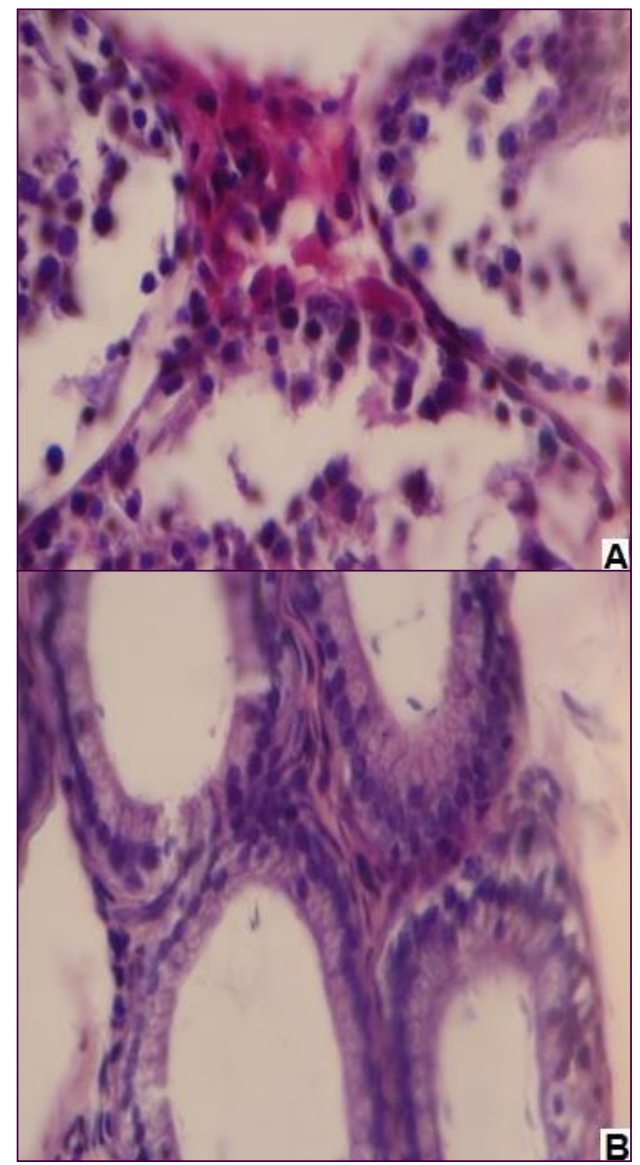

Fig. 4- Testis of diabetic animals showing $(\mathrm{A})$ irregular seminiferous tubules lined with few spermtogenic cells. Giant multinucleated cells appear in the lumen of the tubules and (B) epididymis with no sperm reserve $(\mathrm{H} \& \mathrm{E}) \mathrm{X} 400$

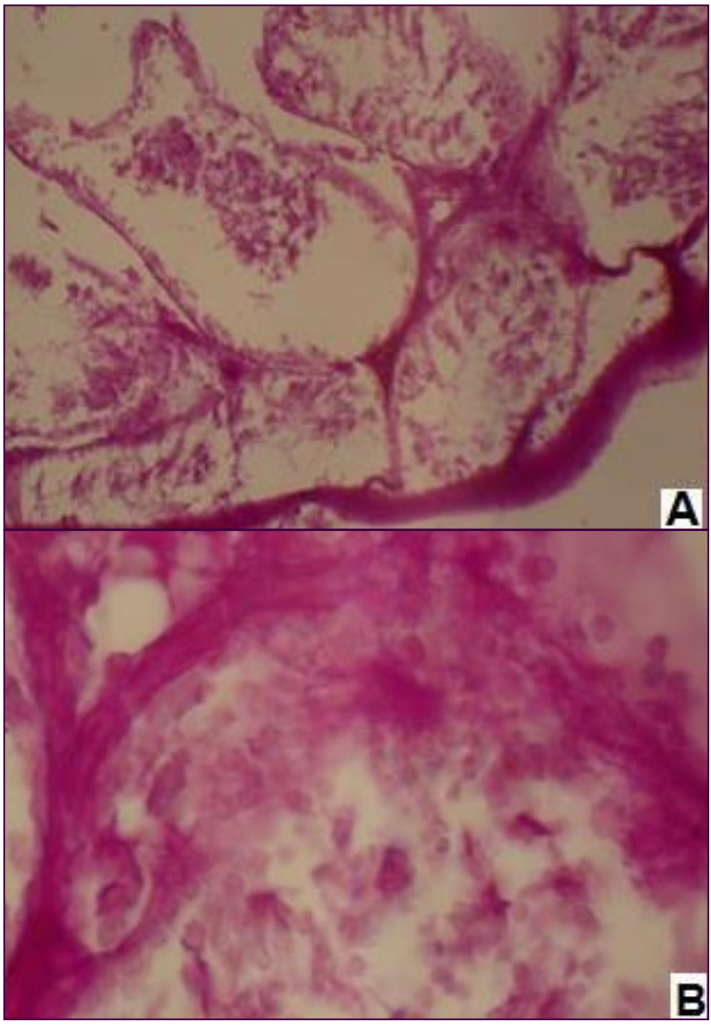

Fig. 5- Testis of diabetic animal (A) \& (B) showing PAS positive apparently thickened basement membrane of the seminiferous tubules. Notice that PAS positive reaction of acrosomal caps is nearly absent in the cells lining the wall of the tubules. PAS (A) X100,PAS X400

\section{Discussion}

Results showed that $A$. thaliana ethanolic seed extract has hyperglycemic activity as compared to the control treatment. The effect of the insulin-like protein and the active compounds such as flavonoids that found in $A$. thaliana caused a significant decrease in blood glucose levels in diabetic mice similar to that reported on the hypoglycemic activity of $A$. thaliana by Weili et al., who reported that an important therapeutic protein human insulin-like growth factor 1 (hIGF-1) called somatomedin $\mathrm{C}$, was expressed in $A$. thaliana seeds via oleosin fusion technology [19].

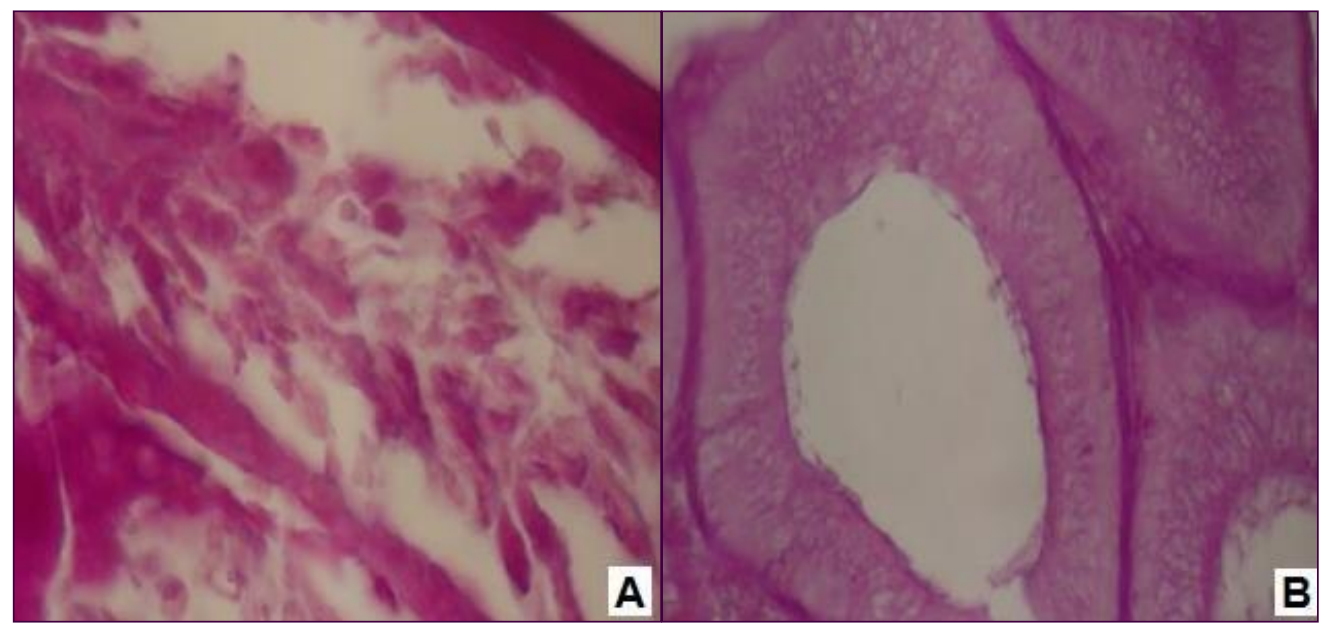

Fig. 6- testis of diabetic animal showing (A) apparently thickened PAS positive basement membrane. Few acrosomal caps of early spermatids and few late spermatids were noticed and $(\mathbf{B})$ epididymis with apparently thickened basement membrane and luminal border. PAS X400 
Taha M.A., Ahmed S.J. and Rashid K.I.

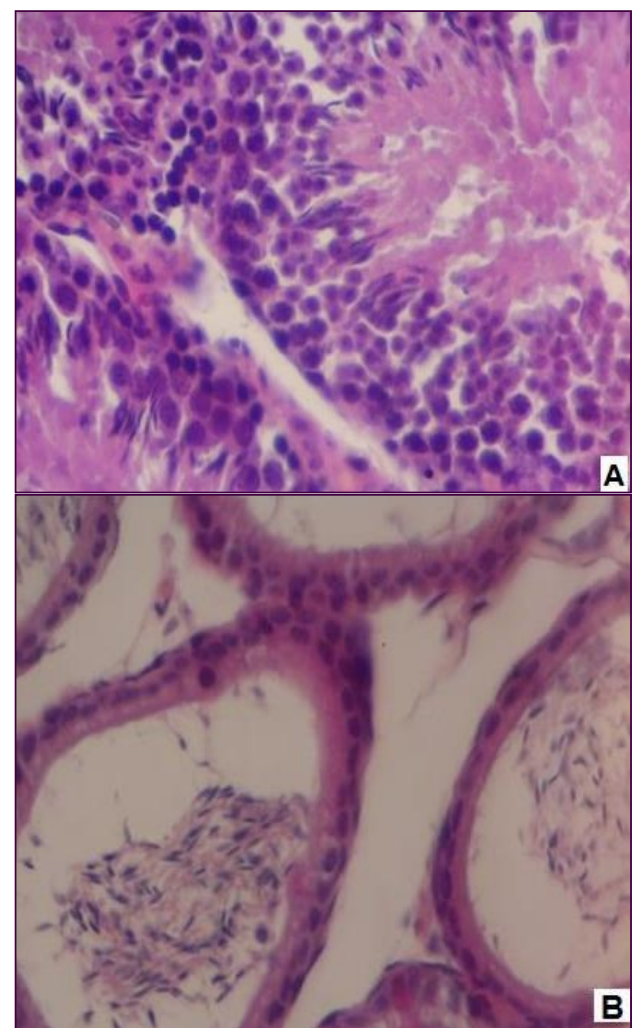

Fig. 7- Testis of Arabidopsis treated diabetic animals showing (A) seminiferous tubules with normal structure and (B) epididymis with sperm reserve (H\&E) X400

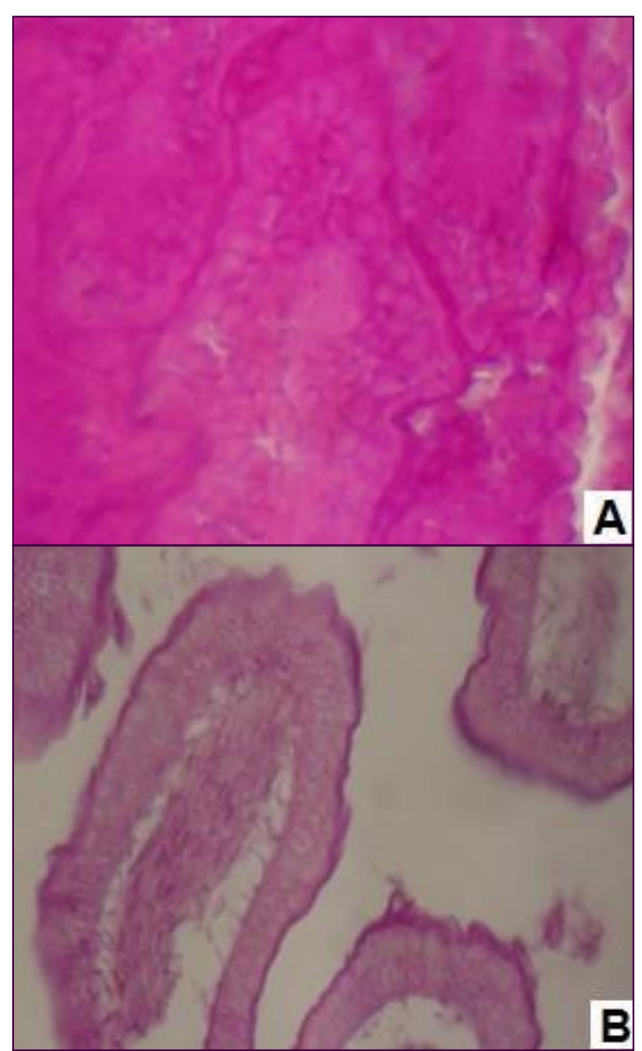

Fig. 8- Testis of Arabidopsis treated diabetic animal showing (A) PAS positive reactions of basement membrane and acrosomal caps of early spermatids and late spermatids nearly similar to the control group and $(\mathbf{B})$ epididymis nearly similar to control group
The histological changes of testicular tissue in diabetic group were similar and in accordance with the previous studies which reported the degeneration and necrosis of seminiferous tubules, giant cell formation and interstitial changes [20-22]. The current study showed thickening of the seminiferous tubules basement membrane of diabetic non-treated animals in $\mathrm{H}$ and $\mathrm{E}$ and PAS stained sections. It might be due to impairment of the turnover of basement membrane proteins, as these proteins were glycosylated in diabetic animals [23]. Thus, it is possible that the increase in basement membrane thickening preceded the failure of spermatogenesis. The basement membrane acted as a reservoir for growth factors and served as a selective filtration barrier for macromolecules between the stroma and the epithelium [24]. A loss of anionic binding sites has been postulated to play a role in the altered permeability of the basement membrane in diabetics [25]

An alteration in the binding properties of the seminiferous tubules basement membrane could indirectly impair spermatogenesis by restricting access of the seminiferous epithelium to various hormones and paracine factors that have been previously shown to play a role in the regulation of spermatogenesis [26]. In diabetic rats treated with Arabidopsis, the all histologic observations seemed to be improved in comparison with untreated diabetic rats. These findings specify that, Arabidopsis can be able to diminish the side effects of diabetes on the function and structure of reproductive system through the lowering of the elevated blood glucose levels.

Histopathological investigation of the epididymis and seminiferous tubules of the control group showed normal sperm reserve and spermatogenesis respectively. Histological findings of the epididymis for diabetic group revealed reduced sperm reserve. Reduced sperm reserve in the epididymis is due to oxidative stress causing inhibition of spermatogenesis as evidenced by the changes in the seminiferous tubules of the diabetic group which showed extensive fibrosis. The decreased sperm reserve due to oxidative stress is found to be associated with an increased number of abnormal forms of spermatozoa due to DNA damage [27]. Oxidative stress in these structures is ameliorated by administration of Arabidopsis as evidenced by improved histological changes. Abe and his group $[27,28]$ have describedthat principal cells in segment II (caput) secrete PASpositivematerial in the lumen which is utilized bysperm during maturation in subsequent segments, andthat in absence of sperm, such material is reabsorbed by the principal cells of segment IV (corpus) ofepididymis. Thus, thickening of PAS-positive luminal border in epithelial cells of epididymis might be because of absence or reduced number of sperm in epididymallumen. In conclusion, the present results showed that Arabidopsis consumption reversed most of the histological changes in the diabetic mice. This effect was due to the hypoglycemic effect of the Arabidopsis and improving the insulin resistance and this agreement with Rashid, et al [29]. In addition, in diabetes there was an increase in the oxidative stress which was significantly reduced by Arabidopsis consumption owing to its antioxidant effect.

Conflicts of Interest: None declared.

\section{References}

[1] Sommerville C. \& Koornneef M. (2002) Nature Reviews Genetics, 3, 883-889.

[2] Li W., Li L., Li K., Lin J., Sun X. \& Tang K. (2011) Biotechnology and Applied Biochemistry, 58(3), 139-146. 
[3] Kokate R.N. (1994) Practical Pharmacognosy, 3rd ed., Vallabh Prakashan New Delhi, 107-109.

[4] Evans W.C. (1989) Pharmacognosy, 13th ed., Balliere Tindal, London, 419-420.

[5] Alsereita M. \& Abu-Amer K. (1996) 40th Annul of the Egy. Soc. Of Pharmacol. Ant Therap., Cairo, 44.

[6] Harborne J.B. (1984) Phytochemical Methods, A guide to Modern Technique of Plant Analysis, Chapman Hall, London.

[7] Altay B., Cetinkalp S., Doganavşargil B., Hekimgil M. \& Semerci B. (2003) Fertil. Steril., 80(2), 828-831.

[8] Baccetti B., La Marca A., Piomboni P., Capitani S., Bruni E., Petraglia F. \& De Leo V. (2002) Human Reproduction, 17(10), 2673-2677.

[9] Scarano W.R., Messias A.G., Oliva S.U., Klinefelter G.R. \& Kempinas W.G. (2006) International Journal of Andrology, 29 (4), 482-488.

[10]Suthagar E., Soudamani S., Yuvaraj S., Ismail Khan A., Aruldhas M.M. \& Balasubramanian K. (2009) Biomedicine \& Pharmacotherapy, 63(1), 43-50.

[11]Hassan A.A., Hassouna M.M., Taketo T., Gagnon C. \& Elhilali M.M. The Journal of Urology, 149(1), 148-154.

[12]Olivares A., Méndez J.P., Cárdenas M., Oviedo N., Palomino M. Á., Santos I. \& Ulloa-Aguirre A. (2009) General and Comparative Endocrinology, 161(3), 304-312.

[13]Singh S., Malini T., Rengarajan S. \& Balasubramanian K. (2009) Journal of Cellular Biochemistry, 108(5), 1094-1101.

[14]Sudha S., Valli G., Julie P.M., Arunakaran J., Govindarajulu P. \& Balasubramanian K. (2000) Experimental and Clinical Endocrinology \& Diabetes, 108(01), 14-20.

[15]Cai L., Chen S., Evans T., Deng D.X., Mukherjee K. \& Chakrabarti S. (2000) Urological Research, 28(5), 342-347.

[16]Guneli E., Tugyan K., Ozturk H., Gumustekin M., Cilaker S. \& Uysal N. (2008) European Surgical Research, 40(4), 354-360.

[17]Vincent A.M., Russell J.W., Low P. \& Feldman E.L. (2004) Endocrine Reviews, 25(4), 612-628.

[18]Bancroft J.D. \& Stevens A. (1996) Theory and Practice of Histological Techniques, 4th ed., Churchill Livingstone: New York.

[19]Li W., Li L., Li K., Lin J., Sun X. \& Tang K. (2011) Biotechnology and Applied Biochemistry, 58(3), 139-146.

[20]Sanguinetti R.E., Ogawa K., Kurohmaru M. \& Hayashi Y. (1995) Experimental Animals/Japanese Association for Laboratory Animal Science, 44(1), 71-73.

[21]Oztürk F., Gül M., Agkadir M. \& Yagmurca M. (2002) T. Kin. J. Med. Sci., 22, 173-178.

[22]Anderson J.E. \& Thliveris J.A. (1986) The Anatomical Record, 214(4), 378-382.

[23]Nicholls K. \& Mandel T.E. (1989) Laboratory Investigation; A Journal of Technical Methods \& Pathology, 60(4), 486-491.

[24]Timpl R. (1993) Experientia, 49(5), 417-428.

[25]Skinner M.K. (1991) Endocrine Reviews, 12(1), 45-77.

[26]Aitken R.J. \& De luliis G.N. (2004) Basic Sci. Reproductive Med., 199(2-3), 219-230.

[27]Abe K., Takano H. \& Ito T. (1983) Anat. Rec., 207, 17-24.
[28]Abe K., Takano H. \& Ito T. (1987) Journal of Reproduction and Fertility, 64(1), 69-72.

[29]Rashid K.I., Aljibouri A.M., Zayer A.A., Khalid L.B. \& AbdulMunaem A. (2013) Iraqi J. Pharm. Sci., 22(1), 115-119. 